\title{
Awareness And Attitude Towards Preventive Measures Of Covid 19 Transmission In Dental Practice Among Delhi - NCR (India) Dental Surgeons: A Cross Sectional Survey
}

Kanika Jain $^{1 *}$, VijayaDhar Bhatt ${ }^{2}$, Chetna Arora ${ }^{3}$, Shubhra Malik ${ }^{4}$, Jyotsana Sikri ${ }^{5}$, Aakriti ${ }^{6}$

${ }^{1}$ Post Graduate Student, Department of Conservative Dentistry and Endodontics, Santosh Deemed to be University, Ghaziabad, India.

${ }^{2}$ Professor and Head, Department of Conservative Dentistry and Endodontics, Santosh Deemed to be University, Ghaziabad, India.

${ }_{3}^{3}$ Professor, Department of Conservative Dentistry and Endodontics, Santosh Deemed to be University, Ghaziabad, India.

${ }^{4}$ Reader, Department of Conservative Dentistry and Endodontics, Santosh Deemed to be University, Ghaziabad, India.

${ }^{5}$ Senior Lecturer, Department of Conservative Dentistry and Endodontics, Santosh Deemed to be University, Ghaziabad, India.

${ }^{6}$ Senior Lecturer, Department of Conservative Dentistry and Endodontics, Santosh Deemed to be University, Ghaziabad, India.

\section{Abstract}

\begin{abstract}
Aim \& Objective: In spite of the growing risk of transmission of COVID 19, this study assessesthe level of awareness and attitude of various dental professionals in the Delhi - NCR region (India) towards the preventive measures of COVID 19 transmission in their day to day clinical practice.

Method: The study population included dental surgeons who work in university dental clinics, private sector and government sector in Delhi - NCR (India) region. An online questionnaire was sent to a sample of Delhi NCR (India) dental surgeons in October 2020. The questionnaire comprised of a series of questions about their demographic data, their awareness about the incubation period of COVID-19, infection control measures to prevent cross infection in dental settings and their attitude towards the patients while treating to prevent the risk of transmission of COVID 19.

Result: This study included 128 dental surgeons aged 22 to 73 years. A total of 65(51.2\%) dental surgeons were working in university dental clinics, $46(36.2 \%)$ in private clinics and $16(12.6 \%)$ in government set ups. A total of $83(65.4 \%)$ dental surgeons reported that the incubation period of COVID 19 is 2-14 days. Majority of dental surgeonsworking in the university, private and government set upswere well aware about the prevention protocols to avoid the risk of transmission of COVID 19 like the anti retraction hand piece preventive used to avoid the dental operatory water unit contamination, pre procedural mouth rinses and surface disinfection. A total of 72 (58.1\%) dental surgeons were using Grade 3 Personal Protective Equipment (PPE) protocol even for non - aerosol generating procedures. They were using HEPA filters for reducing aerosol transmission inside the operatory and scheduling the aerosol procedures as the last procedure of the day.

Conclusion: Irrespective of the University, private and governmentdental clinics, Delhi - NCR (India) dental surgeons were well aware about the COVID 19 mode of transmission, infection control and appropriate measures to be taken to prevent the transmission of COVID 19 in their dental practices.
\end{abstract}

Keywords: COVID 19; Infection Control; Dental Surgeons; PPE; Transmission; nCoV; Coronavirus; SARS - CoV-2.

\section{Introduction}

The present outbreak of COVID-19 (Corona VIrus Disease 2019) is a global concern constituting public health emergency. Itwas first reported in the sea food markets of Hubei province of Wuhan, China, in December 2019, which was later spread globally [1]. COVID-19 has seen a violent and fast-spreading virus around the world, which led to the declaration of a pandemic outbreak of coronavirus by World Health Organization (WHO) in March 2020. As the exact nature of the disease is still unknown, it is believed to spread through direct/indirect human to human transmission or through body fluids, including saliva [2].

Since December 2019, various unexplained cases of pneumonia-

\footnotetext{
*Corresponding Author:

Kanika Jain,

Post Graduate Student, Department of Conservative Dentistry and Endodontics, Santosh Deemed to be University, Ghaziabad, U.P.-201009, India.
} Email Id: kanikajain226@gmail.com

Received: February 22, 2021

Accepted: April 04, 2021

Published: April 08, 2021

Citation: Kanika Jain, VijayaDhar Bhatt, Chetna Arora, Shubhra Malik, Jyotsana Sikri, Aakriti. Awareness And Attitude Towards Preventive Measures Of Covid 19 Transmission In Dental Practice Among Delhi - NCR (India) Dental Surgeons: A Cross Sectional Survey. Int J Dentistry Oral Sci. 2021;08(04):2296-2301. doi: http://dx.doi.org/10.19070/23778075-21000454

Copyright: Kanika Jain ${ }^{\circ} 2021$. This is an open-access article distributed under the terms of the Creative Commons Attribution License, which permits unrestricted use, distribution and reproduction in any medium, provided the original author and source are credited. 
like symptoms were reported in China. This SARS-CoV-2 came to be known as COVID-19 (COrona VIrus Disease 2019) by WHO in February 2020 [3]. The virus was suspected to begin its spread from the Huanan seafood wholesale market of Wuhan, China, with the possibility that an animal carrying the virus was brought and sold into the market. However, the most likely possibility is that virus originated from bats and pangolins [4].

Globally, more than 58 million people are confirmed with cases of COVID-19 so far [5]. As the first case was reported in Wuhan, a city in Hubei Province of China on 18 December 2019, till the end of 2019, all the continents were affected by this disease except Antarctica [5]. In India, first COVID case was reported on 30 January, 2020 with the largest number of cases among Asian countries and second largest number of cases in the world after USA [6].

It has been seen that COVID positive patients can show symptoms after an incubation period of about 2 to 14 days which depends on patient's age, past medical history and immune status. [7]. The most common symptoms seen in this disease are fever, cough, fatigue, shortness of breath being the pathognomic sign while the patient can also present with cough, headache, diarrhoea, lymphopenia and dyspnoea which truly depicts the multifaceted nature of the virus [8].

\section{COVID 19 and Dental Treatment}

Due to the inherent characteristics of dental clinics as well as the involvement of blood, saliva and aerosol production during the dental procedures, usually seen a greater risk of cross contamination between the dental surgeons and the patients [9][10]. COVID 19 can spread through the inhalation of aerosols from COVID positive patients as well as the direct or indirect contact of mucous membrane and contaminated instruments of infected patients $[10,12]$. Given the exposure risk for various working categories, dental practitioners are categorized as the first line warriors keeping in view the greatest risk of COVID 19 transmission. This poses a great challenge for the dental clinicians to continue their practices in these tough times.

Due to the distinct characteristics of various dental procedures, large number of droplets and aerosols are produced which cannot be avoided from standard protocols in day to day practice. Dental health care workers are therefore required to upgrade their knowledge and skills in relation to the new patient management approaches and infection control measures in their daily dental practices. In addition to this, dental surgeons are requested to follow the protocols recommended by higher authorities in order to prevent or reduce the risk of cross contamination.

Hence, this study focuses on assessing the levels of awareness and attitude of various dental professionals in the Delhi - NCR region (India) towards the preventive measures of COVID 19 transmission in their day to day practice.

\section{Material And Method}

\section{Study Population}

The study population comprised of dental surgeons who worked in Delhi NCR region (India) regardless of whether they work in private, university or government dental clinics. This survey was conducted in October 2020 after taking the ethical clearance from Santosh Deemed to be University, Ghaziabad, India. An online questionnaire using Google form was used to collect the data. The samples of dental surgeons were selected from the facebook groups and were sent the questionnaire accordingly. Selected dental surgeons were requested to participate voluntarily after explanation of the purpose of the study and confidentiality of the responses was assured.

\section{Survey Tool}

A self explanatory close ended questionnaire was administered with a total of 16 questions pertaining to sociodemographic data of the dental surgeons, their knowledge regarding COVID 19 and attitude towards the prevention of transmission of COVID 19. The survey comprised of multiple choice questions in the questionnairefurther divided into three sections: dental surgeons demographic data, awareness towards the incubation period of COVID 19, concentration of hypochlorite used as a disinfectant, methods to prevent cross contamination and attitude towards the risk of cross contamination of aerosol production and its prevention, n95 masks and Personal Protective Equipment (PPE).

\section{Results}

\section{Statistical Analysis}

The categorical variables were presented as absolute numbers and percentage. The software used for the statistical analysis wasSPSS (Statistical Package for Social Sciences) version 25.0.The test of significance used in this study was chi-square test to compare two

Table 1. Dental surgeon's demographic data.

\begin{tabular}{|c|c|c|c|}
\hline & & Frequency & Percentage \\
\hline \multirow{3}{*}{ Designation } & PG student & 46 & $35.90 \%$ \\
\cline { 2 - 4 } & Private Clinic & 27 & $21.10 \%$ \\
\cline { 2 - 4 } & UG student & 55 & $43.00 \%$ \\
\hline \multirow{2}{*}{ Age } & $30-60$ years & 11 & $8.60 \%$ \\
\cline { 2 - 4 } & Less than 30 years & 117 & $91.40 \%$ \\
\hline \multirow{2}{*}{$\begin{array}{c}\text { Currently } \\
\text { working in }\end{array}$} & Government sector & 16 & $12.50 \%$ \\
\cline { 2 - 4 } & Private sector & 47 & $36.70 \%$ \\
\cline { 2 - 4 } & University Clinics & 65 & $50.80 \%$ \\
\hline
\end{tabular}


groups of dental surgeons working in university dental clinics and private clinics.

\section{Participant's Characterstics}

The study included 128 participants aged 22 to 73 years where maximum participating dental surgeons $(93 \%)$ were included under the age of 30 years. A total of $65(51.2 \%)$ were working in university dental clinics, $46(36.2 \%)$ in private clinics and $16(12.6 \%)$ in government set ups.

\section{Awareness Among Dental Surgeons About Transmission Of Covid 19}

No significant difference was found in relation tothe comparison of incubation period of COVID-19. Hand piece is recommended to prevent cross contamination in dental settings, concentration of sodium hypochlorite used as a surface disinfectant as well as disinfection of water lines and concentration of hydrogen peroxide used for pre-procedural rinse to minimize the bacterial load between University dental clinics and private sector. People working in both sectors were well aware of all the Standard Operating Protocols (SOP's).

Dental surgeons working in both sectors were well aware aboutthe methods of prevention of cross contamination namely rubber dam, dental aerosol reduction test as well as extra oral suction. About $79 \%$ (102) of the dental surgeons gave the right answer and most of the dental surgeons (50\%) did not reuse the masks or if required, used them only three times daily.

\section{Attitude Of Dental Surgeons Towards The Prevention Of Covid 19 Transmission}

Dental surgeons in both sectors were well educated and aware about the COVID 19 transmission risks and their prevention. Most of them implemented HEPA filters (24\%) and exhaust fans $(20 \%)$ in their clinics to prevent the aerosol transmission.

Most of the dental surgeonskept their aerosol producing appointment as the last appointment of the day. Most of the dental surgeons (57\%) were using Grade 3 PPE protocol even to treat non aerosol generating procedures. Moreover, many of them were changing sleeves while using RVG and disinfecting them with $70 \%$ isopropyl alcohol after every patient.

Most of the dental surgeonskept their aerosol producing appointment as the last appointment of the day. Most of the dental surgeons (57\%) were using Grade 3 PPE protocol even to treat non aerosol generating procedures. Moreover, many of them were

Table 2. Dental Surgeon's awareness towards COVID 19 transmission risks in dental clinics and its prevention.

\begin{tabular}{|c|c|c|c|c|c|c|}
\hline & & \multicolumn{2}{|c|}{ Designation } & \multirow[b]{2}{*}{ Total } & \multirow{2}{*}{$\begin{array}{l}\text { Chi-square } \\
\text { value }\end{array}$} & \multirow[b]{2}{*}{$\mathrm{p}$-value } \\
\hline & & $\begin{array}{l}\text { Universi- } \\
\text { ty Clinics }\end{array}$ & $\begin{array}{l}\text { Private } \\
\text { sector }\end{array}$ & & & \\
\hline \multirow{4}{*}{ Incubation Period of COVID 19} & \multirow{2}{*}{$2-14$ days } & 38 & 6 & 44 & 2.24 & 0.134 \\
\hline & & $37.60 \%$ & $22.20 \%$ & $34.40 \%$ & & \\
\hline & \multirow{2}{*}{ Correct } & 63 & 21 & 84 & & \\
\hline & & $62.40 \%$ & $77.80 \%$ & $65.60 \%$ & & \\
\hline \multirow{4}{*}{$\begin{array}{l}\text { Hand piece recommended to prevent } \\
\text { cross infection in dental settings? }\end{array}$} & \multirow{2}{*}{$\begin{array}{l}\text { Anti-retraction Hand } \\
\text { piece }\end{array}$} & 54 & 16 & 70 & 0.289 & 0.591 \\
\hline & & $53.50 \%$ & $59.30 \%$ & $54.70 \%$ & & \\
\hline & \multirow{2}{*}{ Correct } & 47 & 11 & 58 & & \\
\hline & & $46.50 \%$ & $40.70 \%$ & $45.30 \%$ & & \\
\hline \multirow{4}{*}{$\begin{array}{l}\text { What concentration of sodium } \\
\text { hypochlorite is used as a surface disin- } \\
\text { fectant? }\end{array}$} & \multirow{2}{*}{$1.00 \%$} & 41 & 14 & 55 & 1.102 & 0.294 \\
\hline & & $40.60 \%$ & $51.90 \%$ & $43.00 \%$ & & \\
\hline & \multirow{2}{*}{ Correct } & 60 & 13 & 73 & & \\
\hline & & $59.40 \%$ & $48.10 \%$ & $57.00 \%$ & & \\
\hline \multirow{4}{*}{$\begin{array}{l}\text { What concentration of hydrogen per- } \\
\text { oxide is used for pre-procedural rinse } \\
\text { to minimize the bacterial load? }\end{array}$} & \multirow{2}{*}{$\begin{array}{l}1 \% \text { hydrogen perox- } \\
\text { ide or } 0.2 \% \text { povi- } \\
\text { done }- \text { iodine }\end{array}$} & 72 & 21 & 93 & & \\
\hline & & $71.30 \%$ & $77.80 \%$ & $72.70 \%$ & & \\
\hline & \multirow{2}{*}{ Correct } & 29 & 6 & 35 & & \\
\hline & & $28.70 \%$ & $22.20 \%$ & $27.30 \%$ & 0.452 & 0.501 \\
\hline \multirow{4}{*}{$\begin{array}{l}\text { During cavity preparation, which jaw } \\
\text { region produces highest bio aerosols? }\end{array}$} & \multirow{2}{*}{ Mandibular posterior } & 49 & 11 & 60 & \multirow{4}{*}{3.042} & \multirow{4}{*}{0.551} \\
\hline & & $48.50 \%$ & $40.70 \%$ & $46.90 \%$ & & \\
\hline & \multirow{2}{*}{ Incorrect } & 52 & 16 & 16 & & \\
\hline & & $51.50 \%$ & $59.30 \%$ & $12.50 \%$ & & \\
\hline \multirow{4}{*}{$\begin{array}{l}\text { At what percentage sodium hypochlo- } \\
\text { rite is recommended for disinfection } \\
\text { of dental unit water lines? }\end{array}$} & \multirow{2}{*}{$0.01 \%$} & 39 & 9 & 48 & 3.655 & 0.301 \\
\hline & & $38.60 \%$ & $33.30 \%$ & $37.50 \%$ & & \\
\hline & \multirow{2}{*}{ Incorrect } & 62 & 18 & 80 & & \\
\hline & & $61.40 \%$ & $66.70 \%$ & $62.50 \%$ & & \\
\hline
\end{tabular}


Table 3. Dental surgeon's awareness about the methods of cross contamination \& use of masks.

\begin{tabular}{|c|c|c|c|c|c|c|}
\hline & & \multicolumn{2}{|c|}{ Designation } & \multirow[b]{2}{*}{ Total } & \multirow[b]{2}{*}{$\begin{array}{l}\text { Chi-square } \\
\text { value }\end{array}$} & \multirow[b]{2}{*}{ p-value } \\
\hline & & $\begin{array}{l}\text { Universi- } \\
\text { ty Clinics }\end{array}$ & $\begin{array}{l}\text { Private } \\
\text { sector }\end{array}$ & & & \\
\hline \multirow{4}{*}{$\begin{array}{l}\text { Which of the following } \\
\text { method you think can pre- } \\
\text { vent cross contamination? }\end{array}$} & All & 21 & 7 & 28 & 0.329 & 0.567 \\
\hline & & $20.80 \%$ & $25.90 \%$ & $21.90 \%$ & & \\
\hline & Correct & 80 & 20 & 100 & & \\
\hline & & $79.20 \%$ & $74.10 \%$ & $78.10 \%$ & & \\
\hline \multirow{4}{*}{$\begin{array}{l}\text { If you plan to re - use } \\
\text { your N95/FFP2/respira- } \\
\text { tor after a } 4 \text { day period } \\
\text { of self-disinfection using } \\
\text { a paper bag, how many } \\
\text { times it can be re-used? }\end{array}$} & 3 times & 24 & 4 & 26 & 1.262 & 0.532 \\
\hline & & $23.80 \%$ & $14.80 \%$ & $20.30 \%$ & & \\
\hline & Correct & 77 & 23 & 100 & & \\
\hline & & $76.20 \%$ & $85.20 \%$ & $78.10 \%$ & & \\
\hline
\end{tabular}

Table 4. Measures taken by dental surgeons to reduce the aerosols production in Dental practice/operatory.

\begin{tabular}{|c|c|c|c|c|c|}
\hline \multirow{2}{*}{$\begin{array}{c}\text { What type of workplace controls have } \\
\text { you implemented in your clinical } \\
\text { practice to reduce the aerosol inside the } \\
\text { operatory? }\end{array}$} & \multicolumn{2}{|c|}{ Designation } & \multirow[b]{2}{*}{ Total } & \multirow[b]{2}{*}{$\begin{array}{l}\text { Chi-square } \\
\text { value }\end{array}$} & \multirow[b]{2}{*}{$\begin{array}{c}\mathrm{p}- \\
\text { value }\end{array}$} \\
\hline & $\begin{array}{c}\text { University } \\
\text { Clinics }\end{array}$ & $\begin{array}{l}\text { Private } \\
\text { sector }\end{array}$ & & & \\
\hline \multirow[t]{2}{*}{ None } & 23 & 2 & 25 & & \\
\hline & $22.80 \%$ & $7.40 \%$ & $19.50 \%$ & & \\
\hline \multirow[t]{2}{*}{ Exhaust fans } & 23 & 6 & 26 & & \\
\hline & $22.80 \%$ & $22.20 \%$ & $20.30 \%$ & & \\
\hline \multirow[t]{2}{*}{ HEPA filters } & 23 & 8 & 31 & 4.797 & 0.441 \\
\hline & $22.80 \%$ & $29.60 \%$ & $24.20 \%$ & & \\
\hline \multirow{2}{*}{ Negative pressure rooms } & 13 & 5 & 18 & & \\
\hline & $12.90 \%$ & $18.50 \%$ & $14.10 \%$ & & \\
\hline \multirow[t]{2}{*}{ UV radiation devices } & 19 & 4 & 23 & & \\
\hline & $18.80 \%$ & $14.80 \%$ & $18.00 \%$ & & \\
\hline
\end{tabular}

Table 5. Dental surgeon'sattitude towards the prevention of COVID 19 crosses contamination.

\begin{tabular}{|c|c|c|c|c|c|c|}
\hline & & \multicolumn{2}{|c|}{ Designation } & \multirow[b]{2}{*}{ Total } & \multirow{2}{*}{$\begin{array}{l}\text { Chi-square } \\
\text { value }\end{array}$} & \multirow[b]{2}{*}{ p-value } \\
\hline & & $\begin{array}{l}\text { University } \\
\text { Clinics }\end{array}$ & $\begin{array}{l}\text { Private } \\
\text { sector }\end{array}$ & & & \\
\hline \multirow{4}{*}{$\begin{array}{l}\text { How do you schedule } \\
\text { your aerosol generating } \\
\text { appointments? }\end{array}$} & Correct & 46 & 19 & 65 & 6.016 & $0.049 *$ \\
\hline & & $45.50 \%$ & $70.40 \%$ & $50.80 \%$ & & \\
\hline & \multirow{2}{*}{ Last appointment of the day } & 55 & 8 & 56 & & \\
\hline & & $50.00 \%$ & $29.60 \%$ & $43.80 \%$ & & \\
\hline \multirow{8}{*}{$\begin{array}{l}\text { In your opinion, what } \\
\text { should be the PPE } \\
\text { protocol undertaken for } \\
\text { non - aerosol generating } \\
\text { clinical procedures? }\end{array}$} & \multirow{2}{*}{$\begin{array}{l}\text { Face / eye shields, surgical latex gloves } \\
\text { and N95/ FFP3 respirators. }\end{array}$} & 6 & 4 & 7 & & \\
\hline & & $5.90 \%$ & $14.80 \%$ & $5.50 \%$ & & \\
\hline & \multirow{2}{*}{$\begin{array}{c}\text { Grade } 1 \text { ( Head cap, surgical mouth } \\
\text { masks, surgical latex gloves, face shield) }\end{array}$} & 13 & 3 & 16 & & \\
\hline & & $12.90 \%$ & $11.10 \%$ & $12.50 \%$ & & \\
\hline & \multirow{2}{*}{$\begin{array}{l}\text { Grade } 2 \text { (Head cap, N95 respirators, } \\
\text { surgical latex gloves, face/ eye shields) }\end{array}$} & 24 & 5 & 29 & & \\
\hline & & $23.80 \%$ & $18.50 \%$ & $22.70 \%$ & & \\
\hline & \multirow{2}{*}{$\begin{array}{l}\text { Grade } 3 \text { (Head cap, N95 respirators/ } \\
\text { higher or equivalent, isolation gowns } \\
\text { with hood and shoe covers, face / eye } \\
\text { shields) }\end{array}$} & 58 & 15 & 73 & & \\
\hline & & $57.40 \%$ & $55.60 \%$ & $57.00 \%$ & & \\
\hline \multirow{8}{*}{$\begin{array}{l}\text { What are you using to } \\
\text { disinfect RVG sensors } \\
\text { after every patient? }\end{array}$} & \multirow{2}{*}{$70 \%$ Isopropyl alcohol } & 32 & 6 & 38 & 4.487 & 0.344 \\
\hline & & $31.70 \%$ & $22.20 \%$ & $29.70 \%$ & & \\
\hline & \multirow{2}{*}{ Changing the RVG sleeves } & 45 & 14 & 56 & & \\
\hline & & $44.60 \%$ & $51.90 \%$ & $43.80 \%$ & & \\
\hline & \multirow{2}{*}{ No RVG use } & 13 & 6 & 19 & & \\
\hline & & $12.90 \%$ & $22.20 \%$ & $14.80 \%$ & & \\
\hline & \multirow{2}{*}{ Ultra violet radiations } & 9 & 1 & 10 & & \\
\hline & & $8.90 \%$ & $3.70 \%$ & $7.80 \%$ & & \\
\hline
\end{tabular}


changing sleeves while using RVG and disinfecting them with $70 \%$ isopropyl alcohol after every patient.

\section{Discussion}

This survey provides an insight on the level of awareness as well as the attitude of Delhi - NCR (India) dental surgeons against COVID 19 at the time of outbreak in 2020. This survey included a sample of dental surgeons practicing mainly in the Delhi- NCR region (India).

The estimated incubation period of COVID 19 is 2- 14 days [7]. Dental surgeons in this study had varied knowledge about the incubation period but ideally they are expected to know the right incubation period because of its importance in determining the safe period to treat patients [13]. Hence, the current approach to prevent COVID 19 includes practicing proper sanitization protocols as every patient is considered a potential carrier andeven to practice measures to prevent cross contamination [14]. Inspite of the evidence based studies, the dental surgeons had lower level of knowledge about respiratory diseases and infection control [15, 16]. But according to our survey study, Dental surgeons in DelhiNCR (India) are very well aware about the preventive measures and sanitization protocolsto be practiced in these turbulent times. Majority of the dental surgeons $(n=86 / 128,66 \%)$ participated in this study irrespective of whether they were working in university dental clinics, private clinics or government set ups were well aware about the incubation period of the disease. About half of the dental surgeons ( $\mathrm{n}=75 / 128,57,7 \%)$ knew about the concentration of sodium hypochlorite to be used as a surface disinfectant as well as to clean dental unit water lines [17]. Many dental surgeons recommended anti retraction hand pieces $(n=58 / 128$, $44.6 \%$ ) to prevent cross contaminationas they are designed with anti-retraction valves which are effective in preventing droplets and aerosol transmission [18]. Pre-operative antimicrobial mouth rinses are recommended to reduce the microbial load in the oral cavity [19]. Oxidative agent containing mouth rinses with $1 \%$ hydrogen peroxide or $0.2 \%$ povidone-iodine is encouraged as it might reduce the load of corona virus in saliva [20]. Almost every dental surgeon( $\mathrm{n}=102 / 128,80 \%$ ) believed that rubber dam, dental aerosol reduction test and high volume suctionwere capable of removing droplets in the oral cavity and should be used to minimize the aerosol spatter in dental settings [21].

While assessing the attitude of Delhi - NCR (India) dental surgeons against COVID 19 prevention, it has been seen that either they are using N95 masks one time or maximum up to 3 times in a day [[22]., Most of the dental surgeons are even using UV radiation devices $(n=232,18.4 \%)$, HEPA filters $(n=31,25 \%)$ and exhaust fans $(n=26,21 \%)$ to improvethe ventilation and ultimately removing the aerosols from the dental office [23, 24]. More than half of the dental surgeons $(n=75,59 \%)$ used Grade 3 PPE protocols for managing non aerosol generating procedures [22]. Due to the various disinfection protocols, about half of the participating dental surgeons scheduled aerosol procedure as the last procedure of the day [25].

The present questionnaire was designed to assess the knowledge as well as the measures taken by Delhi NCR (India) dental surgeons to combat COVID 19 in this pandemic outbreak era by asking a limited number of simple and clear questions. In this survey, all questions were answered and the results were not contradictory, showing an overall good compliance from the dental practitioners of Delhi NCR region (India).

\section{Conclusion}

Irrespective of the university dental clinics, private clinics and government set ups, Delhi - NCR (India) dental surgeonswere well aware about the COVID 19 mode of transmission, infection control and measures taken to prevent transmission of COVID 19 in their dental practices. They were properly following all the standard operating protocols as governed by the concerned authorities.

As per the current clinical recommendations, it is expected that dental surgeons should be made fully aware about the various risks of transmission, the ability to identify patients with infections, and providing self-protection against 2019-novel CoV. They should treat every patient as a potential carrier of COVID 19 infection and should accordingly take effective infection control measures to control the spread of the disease and ensure safety of themselves, their team as well as the patients to prevent cross contamination and practicing dentistry in the safest possible manner in these turbulent times.

\section{References}

[1]. Lai CC, Liu YH, Wang CY, Wang YH, Shueh SC, Yen MY, et al. Asymptomatic carrier state, acute respiratory disease, pneumonia due to severe acute respiratory syndrome coronavirus 2 (SARS-CoV-2): facts and myths. J Microbiol Immunol Infect 2020;53(3):404-12.Pubmed PMID: 32173241.

[2]. To KK, Tsang OT, Yip CC, Chan KH, Wu T,Lung DC, et al. Consistent Detection of 2019 Novel Coronavirus in Saliva. Clin Infect Dis 2020;71(15):841-3.Pubmed PMID: 32047895.

[3]. Sun P, Lu X, Xu C, Sun W, Pan B. Understanding of COVID-19 based on current evidence. J Med Virol 2020;92(6):548-51. Pubmed PMID: 32096567.

[4]. Coronaviridae Study Group of the International Committee on Taxonomy of Viruses. The species severe acute respiratory syndrome-related coronavirus: classifying 2019-nCoV and naming it SARS-CoV-2. Nat Microbiol 2020;5(4):536-44.

[5]. Ren LL, Wang YM., Wu ZQ, Z Xiang ZC, Guo L, Xu T, et al. Identification of novel coronavirus causing severe pneumonia in humans: a descriptive study. Chinese Med J 2020; 133(9):1015-24.Pubmed PMID: 32004165.

[6]. Sagar Kulkarni. India becomes the third-worst affected country by a coronavirus, overtakes Russia. Deccan Herald. New Delhi. July 5, 2020.

[7]. Li Q, Guan X, Wu P, Wang X, Zhou L, Tong Y, et al. Early transmission dynamics in Wuhan, China, of novel coronavirus-infected pneumonia. N Engl J Med 2020;382:1199-207.Pubmed PMID: 31995857.

[8]. Nishiura H, Jung SM, Linton NM, Kinoshita R, Yang Y, Hayashi K, et al. The Extent of Transmission of Novel Coronavirus in Wuhan, China, 2020. J Clin Med 2020;9(2):330.Pubmed PMID: 31995857.

[9]. Li ZY, Meng LY. The prevention and control of new coronavirus infection in the department of stomatology. Zhonghua Kou Qiang Yi Xue Za Zhi 2020;55(0):E001. PubmedPMID: 32057210.

[10]. Meng L, Hua F, Bian Z. Coronavirus disease 2019 (COVID-19): emerging and future challenges for dental and oral medicine. J Dent Res 2020;9(5):481-7.PubmedPMID: 32162995.

[11]. Liu L, Wei Q, Alvarez X, Wang H, Du Y, Zhu H, et al. Epithelial cells lining salivary gland ducts are early target cells of severe acute respiratory syndrome coronavirus infection in the upper respiratory tracts of rhesus macaques. J Virol 2011;85(8):4025-30.Pubmed PMID: 21289121.

[12]. Chen J. Pathogenicity and transmissibility of 2019-nCoV-a quick overview and comparison with other emerging viruses. Microb Infect 2020; 22(2):69-71.PubmedPMID: 32032682.

[13]. Gaffar BO, El Tantawi M, Al-Ansari AA, AlAgl AS, Farooqi FA, Almas KM. Knowledge and practices of dentists regarding MERS-CoV. A cross-sectional survey in Saudi Arabia. Saudi Med J. 2019 Jul;40(7):714-720.Pubmed PMID: 31287133 .

[14]. Wang D, Hu B, Hu C, Zhu F, Liu X, Zhang J, et al. Clinical characteristics 
of 138 hospitalized patients with 2019 novel coronavirus-infected pneumonia in Wuhan, China. JAMA. 2020 Feb 07.

[15]. . Baseer M, Ansari S, AlShamrani S, Alakras A, Mahrous R, Alenazi A. Awareness of droplet and airborne isolation precautions among dental health professionals during the outbreak of corona virus infection in Riyadh city, Saudi Arabia. J Clin Exp Dent. 2016 Oct;8(4):e379-e387.PubmedPMID: 27703605.

[16]. Abolfotouh MA, AlQarni AA, Al-Ghamdi SM, Salam M, Al-Assiri MH, Balkhy HH. An assessment of the level of concern among hospital-based health-care workers regarding MERS outbreaks in Saudi Arabia. BMC Infect Dis. 2017 Jan 03;17(1):4.PubmedPMID: 28049440.

[17]. Centers for Disease Control and Prevention, Cleaning and Disinfection for Community Facilities, Centers for Disease Control and Prevention, Atlanta, GA, USA, 2020.

[18]. Samaranayake L, Reid J, Evans D. The efficacy of rubber dam isolation in reducing atmospheric bacterial contamination. ASDC J Dent Child 1989;56(6):442-4. Pubmed PMID: 2681303.

[19]. Centre for Disease Control and Prevention. Infection control: Severe acute respiratory syndrome, coronavirus 2 (SARS-CoV-2). March 9, 2020.

[20]. Marui VC, Souto MLS, Rovai ES, Romai GA, Chambrone AL, Pannuti
CM. Efficacy of preprocedural mouth rinses in a reduction of microorganisms in aerosol: a systemic review. J Am Dent Assoc 2019;150(12):1015-26. [21]. Summary of ADA Guidance during the COVID-19 Crisis. 2020. Available from: https://www.success.ada.org/ /media/cps/files/covid/ covid-19_int_guidance_summary.pdf?utm_source=cpsorg \& utm medium=cpsalertbar\&utm_content=cv-pm-summary-guidance\&utm campaign=covid -19

[22]. Centres for Disease Control and Prevention recommendations for putting on and removing Personal Protective Equipment for treating COVID-19 patients. Available from: https://www.cdc.gov/hai/pdfs/ppe/ppe-sequence.pdf

[23]. Elias B, Bar-Yam Y. Could air filtration reduce COVID-19 severity and spread. New England Complex Systems Institute 2020

[24]. Gopikrishna V, Dutta K, Nawal R. Standard Operation protocol (SOP) for Dental Patients during COVID Pandemic.Indian Endodontic Society. SOP. COVID.2020.Version.1.

[25]. Vandenberghe B, Jacobs R, Bosmans H. Modern dental imaging: a review of current technology and clinical application in dental practice. Eur Radiol 2010;20(11):2637-55.Pubmed PMID: 20544352. 